\title{
Enzyme activity of rat tibialis anterior muscle differs between treatment with triamcinolone and prednisolone and nutritional deprivation.
}

Citation for published version (APA):

Koerts-de Lang, E., Hesselink, M. K. C., Bemelman, W. A., van der Vusse, G. J., Wouters, E. F. M., \& Schols, A. M. W. J. (1999). Enzyme activity of rat tibialis anterior muscle differs between treatment with triamcinolone and prednisolone and nutritional deprivation. European Journal of Applied Physiology and Occupational Physiology, 79(3), 274-279. https://doi.org/10.1007/s004210050506

Document status and date:

Published: 01/01/1999

DOI:

10.1007/s004210050506

Document Version:

Publisher's PDF, also known as Version of record

\section{Document license:}

Taverne

Please check the document version of this publication:

- A submitted manuscript is the version of the article upon submission and before peer-review. There can be important differences between the submitted version and the official published version of record.

People interested in the research are advised to contact the author for the final version of the publication, or visit the DOI to the publisher's website.

- The final author version and the galley proof are versions of the publication after peer review.

- The final published version features the final layout of the paper including the volume, issue and page numbers.

Link to publication

\footnotetext{
General rights rights.

- You may freely distribute the URL identifying the publication in the public portal. please follow below link for the End User Agreement:

www.umlib.nl/taverne-license

Take down policy

If you believe that this document breaches copyright please contact us at:

repository@maastrichtuniversity.nl

providing details and we will investigate your claim.
}

Copyright and moral rights for the publications made accessible in the public portal are retained by the authors and/or other copyright owners and it is a condition of accessing publications that users recognise and abide by the legal requirements associated with these

- Users may download and print one copy of any publication from the public portal for the purpose of private study or research.

- You may not further distribute the material or use it for any profit-making activity or commercial gain

If the publication is distributed under the terms of Article $25 \mathrm{fa}$ of the Dutch Copyright Act, indicated by the "Taverne" license above, 
Esther Koerts-de Lang · Matthÿs K.C. Hesselink

Maarten R. Drost · Ger J. van der Vusse

Emiel F.M. Wouters · Annemie M.W.J. Schols

\section{Enzyme activity of rat tibialis anterior muscle differs between treatment with triamcinolone and prednisolone and nutritional deprivation}

Accepted: 1 October 1998

\begin{abstract}
The maximal activity of a selection of enzymes involved in muscle carbohydrate handling, citric acid cycle and fatty acyl $\beta$-oxidation were studied after treatment with the fluorinated corticosteroid triamcinolone and compared to a similar treatment of the non-fluorinated corticosteroid prednisolone in an equipotent anti-inflammatory dose. Furthermore, because triamcinolone causes loss of body mass and muscle wasting, the effects of triamcinolone were investigated relative to a control group, with the same loss of body mass, due to nutritional deprivation. The study was performed in male Wistar rats in the following treatment groups: TR, triamcinolone treatment $\left(0.25 \mathrm{mg} \cdot \mathrm{kg}^{-1}\right.$. $\mathrm{day}^{-1}$ for 2 weeks), which resulted in a reduction of body mass $(24 \%)$; ND, nutritional deprivation $(30 \%$ of normal daily food intake for 2 weeks) resulting in a similar $(24 \%)$ decrease of body mass as TR; PR, prednisolone treatment $\left(0.31 \mathrm{mg} \cdot \mathrm{kg}^{-1} \cdot \mathrm{day}^{-1}\right.$ for 2 weeks $)$, with a $10 \%$ increase in body mass; FF, free-fed control group, with a $12 \%$ increase in body mass in 2 weeks. Compared to FF, TR induced an increase in phosphofructokinase (PFK) activity $(P<0.01)$, glycogen synthase $[\mathrm{GS}(\mathrm{i}+\mathrm{d})]$ activity $(P<0.05)$ and glycogen content $(P<0.01)$ in the tibialis anterior muscle. The PR and ND caused no alterations in PFK or citrate
\end{abstract}

E. Koerts-de Lang $(\varangle)$ · E.F.M. Wouters · A.M.W.J. Schols Department of Pulmonology,

Nutrition Toxicology and Environment Research Institute

Maastricht, University Hospital Maastricht,

P.O. Box 5800 ,

NL-6202 AZ Maastricht, The Netherlands

M.K.C. Hesselink · M.R. Drost

Department of Movement Sciences,

Nutrition Toxicology and Environment Research Institute

Maastricht and Cardiovascular Research Institute Maastricht,

Maastricht University, Maastricht, The Netherlands

G.J. van der Vusse

Department of Physiology,

Nutrition Toxicology and Environment Research Institute

Maastricht and Cardiovascular Research Institute Maastricht,

Maastricht University, Maastricht, The Netherlands synthase (CS) activity compared to FF. Compared to PR, TR induced an increase in PFK $(P<0.01)$, CS $(P<0.05)$ and $\mathrm{GS}(\mathrm{i}+\mathrm{d})$ activity $(P<0.01)$. Both TR and PR caused an increased muscle glycogen content, being more pronounced in TR $(P<0.05)$. Compared to ND, TR induced an increased CS $(P<0.05)$ and GS(i + d) activity $(P<0.01)$ and glycogen content $(P<0.01)$. The ND resulted in a decreased glycogen content compared to FF $(P<0.05)$. None of the treatments affected the activity of glycogen phosphorylase, $\beta$-hydroxyacyl coenzyme A dehydrogenase and lactate dehydrogenase. It was concluded that corticosteroids led to an increased muscle glycogen content; however, the changes in the enzymes of carbohydrate metabolism were corticosteroid type specific and did not relate to undernutrition, which accompanied the triamcinolone treatment.

Key words Prednisolone $\cdot$ Triamcinolone $\cdot$ Nutritional deprivation $\cdot$ Muscle enzyme activity $\cdot$ Glycogen

\section{Introduction}

Glucocorticoids have been commonly used as anti-inflammatory agents in the treatment of chronic obstructive pulmonary disease (COPD; Ferguson 1993). It has been found that patients with COPD often suffer from respiratory and peripheral skeletal muscle weakness (Gosselink et al. 1996; Hamilton et al. 1995; Tobin 1988). The cause of this muscle weakness in COPD is not yet clear, but among others, muscle wasting related to nutritional depletion (Engelen et al. 1994) and corticosteroids (Decramer et al. 1994) have been suggested as contributing factors. Corticosteroids can be fluorinated to increase their anti-inflammatory potency. However, it has been shown that this results in more severe systemic effects than non-fluorinated corticosteroids (Thalen et al. 1989).

It has been demonstrated in studies on experimental animals that the fluorinated corticosteroid triamcinolone causes muscle wasting and predominantly type $\mathrm{IIx} / \mathrm{b}$ 
atrophy (Dekhuijzen et al. 1995; Koerts-de Lang et al. 1998; Petrof et al. 1995). In addition to histochemical changes, triamcinolone exerts many alterations in muscle energy metabolism, which can also be associated with alterations in muscle function. It has been noticed that triamcinolone caused an increase in glycogen concentration in muscle but the exact mechanism of action of triamcinolone on muscle carbohydrate handling is still a matter of debate. Evidence for increased glycogenesis after triamcinolone treatment has been found, associated with increased lactate concentrations (Shoji et al. 1974). In addition, glutamine release of the rat hindquarter has been observed to be increased (Koerts-de Lang et al. 1995; Welbourne 1988), which implies protein catabolism. Furthermore, triamcinolone has even been shown to cause in vitro uncoupling of oxidative phosphorylation and respiration (Peter et al. 1970), which will probably be reflected in changed muscle enzyme capacities.

The question that remains to be addressed is whether changes in muscle metabolism after triamcinolone treatment are induced by

1. Muscle wasting, related to loss of body mass, or

2. Corticosteroid treatment per se, as studied in a prednisolone group.

We hypothesized that triamcinolone-induced muscle atrophy and increased glycogen content is associated with alterations in the activity of muscle enzymes, involved in carbohydrate and $\beta$-oxidation. In an earlier study we have demonstrated that a similar administration of the non-fluorinated corticosteroid prednisolone in an equipotent glucocorticoid dose (Goodman and Gillman 1990) did not affect muscle mass (Koerts-de Lang et al. 1997). Since triamcinolone has been shown to cause type IIx/b atrophy, a muscle with predominantly type II fibres was studied - the tibialis anterior muscle.

\section{Methods}

Animals

Male Wistar rats $(n=40)$ were treated during 2 weeks. The initial body mass of these animals, aged 12 weeks, ranged from 314 to $345 \mathrm{~g}$. The animals were randomly allotted to four groups, a triamcinolone treated group (TR: $0.25 \mathrm{mg} \cdot \mathrm{kg}^{-1} \cdot \mathrm{day}^{-1}$ triamcinolone acetate i.m., which had an ad libitum food intake, $n=10)$ and three reference groups. Because in previous studies the amount of muscle wasting after triamcinolone treatment has not been explained by the diminished food intake alone (Gardiner et al. 1980) but also by an increased energy expenditure (Koerts-de Lang et al. 1998), we did not introduce a pair-fed group, but introduced a nutritionally deprived group (ND: $0.05 \mathrm{ml} \cdot$ day $^{-1}$ saline i.m.), receiving a food intake of $30 \%$ of normal, calculated to result in a comparable reduction in body mass $(n=10)$. A prednisolone treated group was included which received an equipotent anti-inflammatory dose to triamcinolone (PR: $0.31 \mathrm{mg} \cdot \mathrm{kg}^{-1} \cdot \mathrm{day}^{-1}$ prednisolone i.m.; $n=10$ ), with an ad libitum food intake. Thirdly, a free-fed group (FF: $0.05 \mathrm{ml} \cdot \mathrm{day}^{-1}$ saline i.m.) was included which had an ad libitum food intake $(n=10)$. The corticosteroids dose chosen was comparable to that used in patients with COPD as maintenance therapy or during acute exacerbations.
The diet provided to all animals was SRM-A 1210 pellets (Hopefarms, Woerden, The Netherlands). Water was available ad libitum to all animals. The animals were housed in metabolic cages at a temperature of $23^{\circ} \mathrm{C}$ with a $12 \mathrm{~h}$ dark:light cycle. Food intake and body mass of all animals were measured daily. Veterinary supervision, including regular observation of the health of the animals was performed according to the Dutch National Guidelines of Animal Care. The experiment protocol was approved by the Ethics Committee of Animal Research of the Maastricht University.

Muscle preparation and enzyme determination

The rats were anaesthetized with Nembutal $\left(6 \mathrm{mg} \cdot 100 \mathrm{~g}^{-1}\right.$ body mass, i.p.) after short-term $(<20 \mathrm{~s}) \mathrm{CO}_{2}$ sedation. The tibialis anterior muscle was dissected, immediately weighed and freezeclamped in liquid nitrogen and stored at $-80^{\circ} \mathrm{C}$ until analysis. The muscle was homogenized $(10 \% \mathrm{w} / \mathrm{v})$ in SET-buffer by use of an Ultra-Turrax T25 tissue homogenizer (Janke and Kunkel, GmbH and Co., KG) for four 5-s intervals. At $0^{\circ} \mathrm{C}$, the homogenization process was completed by treatment with ultrasonic sound (Soniprep 150, MSE) for four 15-s intervals. Total protein was assayed from this homogenate using bicinchoninic acid as has been described earlier (Brown et al. 1989; Smith et al. 1985). For enzyme determination, the homogenate was centrifuged $\left(4^{\circ} \mathrm{C}\right)$ for $10 \mathrm{~min}$ at $2100 \mathrm{~g}(3500 \mathrm{rpm})$ and supernatant was assayed for lactate dehydrogenase (LDH, Enzyme Commission no., EC 1.1.1.27; Bergmeyer 1974a), phosphofructokinase (PFK, EC 2.7.1.11; Ling et al. 1966), citrate synthase (CS, EC 4.1.3.7; Shepherd and Garland 1969) and 3-hydroxyacyl coenzyme-A dehydrogenase (HAD, EC 1.1.1.35; Bradshaw 1975) activities using a Cobas Bio centrifugal analyser (La Roche, Basle, Switzerland). Glycogen synthase (GS) activity was assessed on a centrifugal analyser (Cobas Fara, Hoffman La-Roche, Basle, Switserland) in the muscle homogenate at $30^{\circ} \mathrm{C}$. To discriminate between the active GS(i) part of GS and total GS activity GS(i + d), GSi activity was assayed in the absence of glucose-6-phosphate (G6P) while G6P $\left(10 \mathrm{mmol} \cdot 1^{-1}\right)$ was added to the homogenate to assay total GS activity.

Urdine diphosphate (UDP)-glucose was used as starting reagents and formation of UDP was measured according to Danforth (1965). Glycogen phosphorylase (GP) activity was assayed according to Schreiber and Bowling (1990) on a centrifuge analyser and expressed as micromoles per minute per gram wet mass. Both the total GP $(a+b)$ and active form GP(a) of GP were assessed. Part of the muscle was dissolved for $1 \mathrm{~h}$ in $1 \mathrm{~mol} \cdot 1^{-1} \mathrm{NaOH}\left(37^{\circ}\right)$, precipitating glycogen with $96 \%$ ethanol $\left(10 \mathrm{~min}\right.$ at $80^{\circ} \mathrm{C}$ followed by overnight precipitation at $4^{\circ} \mathrm{C}$ ). Subsequently the pellet was hydrolyzed using $1 \mathrm{~mol} \cdot 1^{-1} \mathrm{HCl}$ at $100^{\circ} \mathrm{C}$ for $3 \mathrm{~h}$ after which $\mathrm{HCl}$ was neutralized with a $\mathrm{KCl}$ saturated $\mathrm{KOH} / \mathrm{TRIS}\left(2.1 \mathrm{~mol} \cdot \mathrm{l}^{-1}\right.$ $0.12 \mathrm{~mol} \cdot 1^{-1}$ ) buffer. Glycogen derived glycosyl units were determined using a glucose kit (hexokinase method, Roche) for a centrifuge analyser. Glycogen was analysed on a centrifuge analyser (Cobas Fara, Hoffman La-Roche) and expressed as micromole glycosyl units per gram wet mass.

\section{Statistical analysis}

Differences between all groups were first detected with the Kruskall Wallis test and then assessed using the Mann-Whitney $U$-test, because of the non-normal distribution. Level of significance was determined as $P$ equal to or less than 0.05 . Analyses were performed using the SPSS/PC + (Wessex, Inc, Winnetka, IL, USA) program.

\section{Results}

Animal food intake, body and muscle mass

Food intake of all the rats was comparable before the experimental period $\left( \pm 21 \mathrm{~g} \cdot \mathrm{day}^{-1}\right)$. During treatment, 
food intakes of the FF and PR rats remained stable and was approximately $100 \mathrm{~kJ} \cdot 100 \mathrm{~g}^{-1}$ body mass. Mean food intake of the TR rats decreased after the first injection to 9.7 (SEM 0.5) g at day 3 and then slowly increased until it was not significantly different from that of the FF rats at day 12 [TR 19.8 (SEM 1.0) g, FF 21.5 (SEM 0.5) g]. Mean food intakes of the ND rats remained stable at approximately $7 \mathrm{~g} \cdot \mathrm{day}^{-1}$. As shown in Fig. 1A, body masses of the FF and PR group increased, while body masses of the TR and ND groups decreased. After 2 weeks treatment body masses of the TR and ND rats were significantly lower than those of the FF and PR rats (Table $1, P<0.001$ ). Body mass of the TR rats was slightly lower than of the ND rats $(P<0.05)$. Figure 1B depicts the energy intake per $100 \mathrm{~g}$ body mass. There was no significant change in energy intake per body mass during the treatment period for the FF, PR and ND rats. Energy intake per body
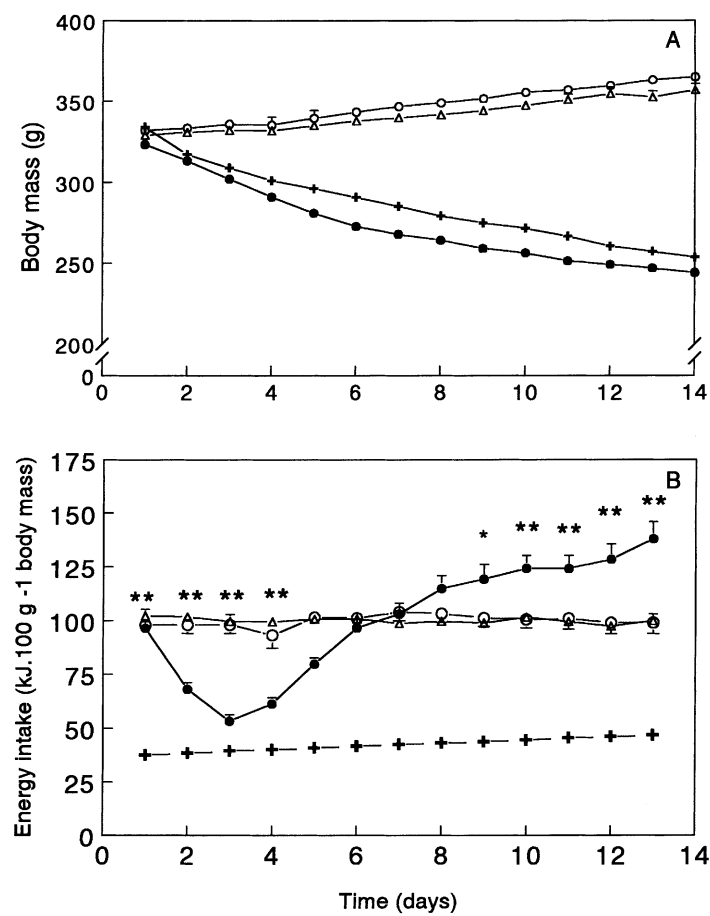

Fig. 1 (A) Mean body mass (SEM) as a result of triamcinolone (TR) $(\mathbf{O})$, prednisolone $(\triangle)$ treatment or nutritional depletion $(+)$ or ad libitum food intake $(\mathrm{FF})(\mathrm{O})$ during experimental period. (B) Mean energy intake (SEM) of the groups during the experiment. Significant difference between TR and FF: ${ }^{*} P<0.05,{ }^{* *} P<0.01$ mass of the TR rats was decreased during the first days and was even increased compared to all other groups 9 days after $(P<0.05)$.

Muscle mass of the tibialis anterior muscle was significantly decreased in the TR and ND group compared to FF and PR (Table $1, P<0.001$ ). Muscle mass was significantly lower in the TR group compared to the ND group $(P<0.001)$. Muscle mass as a percentage of body mass was significantly decreased in the TR group compared to PR and ND $(P<0.001)$, increased in the PR group compared to FF $(P<0.05)$ and even further elevated in the ND group compared to FF $(P<0.001)$.

Muscle glycogen stores and enzyme activities in tibialis anterior muscle

The protein contents per gram muscle wet mass were not significantly different among the groups. Glycogen concentrations in TR and PR were higher than in FF and ND (Fig. 2, $P<0.05$ ), while the glycogen content in TR was significantly higher than in PR $(P<0.05)$. Glycogen content in the ND group was significantly lower than in all other groups $(P<0.05)$. Total $\mathrm{GS}(\mathrm{i}+\mathrm{d})$ activity was significantly increased in the TR group compared to all other groups (Table 2, $P<0.05)$. Maximal activity of the inactive form GS (d) was calculated and significantly increased in TR compared to PR and ND $(P<0.001)$ and FF $(P<0.01)$. The GP activity was no different among the groups. The PFK activity was significantly increased in the tibialis anterior muscle of the TR rats compared to the FF and

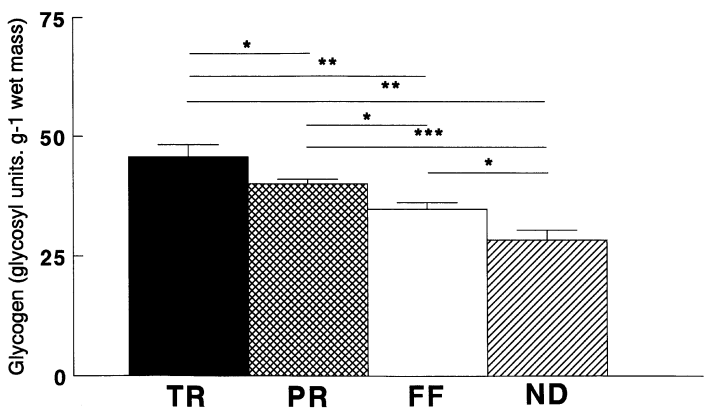

Fig. 2 Mean glycogen content (SEM) in the tibialis anterior muscle of the triamcinolone $(T R)$, prednisolone $(P R)$, nutritional deprived $(N D)$ and control free-fed $(F F)$ group. $* P<0.05, * * P<0.01$, $* * * P<0.001$

Table 1 Body and muscle masses. \% Muscle mass muscle mass of tibialis anterior/body mass $\times 100$

\begin{tabular}{|c|c|c|c|c|c|c|c|c|}
\hline & \multicolumn{2}{|c|}{ Triamcinolone } & \multicolumn{2}{|c|}{ Prednisolone } & \multicolumn{2}{|c|}{ Nutritional deprived } & \multicolumn{2}{|c|}{ Free-fed } \\
\hline & Mean & SEM & Mean & SEM & Mean & SEM & Mean & SEM \\
\hline Body mass (g) & 244 & $2^{\mathrm{a}, \mathrm{b}, \mathrm{e}}$ & 357 & $4^{\mathrm{c}}$ & 254 & $3^{\mathrm{e}}$ & 365 & 2 \\
\hline Tibialis anterior muscle (mg) & 438 & $12^{\mathrm{a}, \mathrm{c}, \mathrm{e}}$ & 748 & $18^{\mathrm{c}}$ & 561 & $11^{\mathrm{e}}$ & 708 & 12 \\
\hline$\%$ Muscle mass & 1.8 & $0.03^{\mathrm{a}, \mathrm{c}}$ & 2.1 & $0.06^{\mathrm{d}}$ & 2.2 & $0.03^{\mathrm{e}}$ & 1.9 & 0.03 \\
\hline
\end{tabular}

${ }^{\mathrm{a}} P<0.001$ compared to $\mathrm{PR},{ }^{\mathrm{b}, \mathrm{c}} P<0.05, P<0.001$ compared to ND, ${ }^{\mathrm{d}, \mathrm{e}} P<0.05, P<0.001$ compared to FF; for definitions see Fig. 2 
Table 2 Muscle enzyme activities in tibialis anterior muscle. $G P$ Glycogen phosphorylase $(a)$ is the active form and $(a+b)$ the total glycogen phosphorylase, $G S$ Glycogen synthase $(i)$ is the active form and $(i+d)$ the total glycogen synthase, PFK Phosphofructokinase, $L D H$ Lactate dehydrogenase HAD, 3-hydroxyacyl coenzyme A dehydrogenase, $C S$ Citrate synthase

\begin{tabular}{|c|c|c|c|c|c|c|c|c|}
\hline & \multicolumn{2}{|c|}{ Triamcinolone } & \multicolumn{2}{|c|}{ Prednisolone } & \multicolumn{2}{|c|}{ Nutritional deprived } & \multicolumn{2}{|c|}{ Free-fed } \\
\hline & Mean & SEM & Mean & SEM & Mean & SEM & Mean & SEM \\
\hline $\mathrm{GP}(\mathrm{a}+\mathrm{b})\left(\mathrm{U} \cdot \mathrm{mg} \operatorname{protein}^{-1}\right)$ & 263 & 12 & 269 & 12 & 240 & 14 & 258 & 16 \\
\hline $\mathrm{GP}(\mathrm{a})\left(\mathrm{U} \cdot \mathrm{mg}\right.$ protein $\left.^{-1}\right)$ & 94 & 8 & 96 & 7 & 78 & 8 & 83 & 6 \\
\hline $\mathrm{GS}(\mathrm{i}+\mathrm{d})\left(\mathrm{U} \cdot \mathrm{mg} \operatorname{protein}^{-1}\right)$ & 38 & $3^{\mathrm{b}, \mathrm{d}, \mathrm{e}}$ & 30 & $1^{\mathrm{c}}$ & 25 & 2 & 28 & 3 \\
\hline GS(i) $\left(\mathrm{U} \cdot \mathrm{mg}\right.$ protein $\left.{ }^{-1}\right)$ & 17 & 1 & 17 & 1 & 15 & 1 & 16 & 1 \\
\hline PFK $\left(\mathrm{U} \cdot \mathrm{g}_{\text {protein }}{ }^{-1}\right)$ & 507 & $127^{\mathrm{b}, \mathrm{f}}$ & 155 & 40 & 217 & 44 & 117 & 40 \\
\hline $\mathrm{LDH}\left(\mathrm{U} \cdot \mathrm{mg}\right.$ protein $\left.^{-1}\right)$ & 10.0 & 0.8 & 12.5 & 1.5 & 10.2 & 1.0 & 10.3 & 0.8 \\
\hline HAD $\left(\mathrm{U} \cdot \mathrm{g}\right.$ protein $\left.^{-1}\right)$ & 118 & 15 & 109 & 15 & 87 & 8 & 89 & 12 \\
\hline $\mathrm{CS}\left(\mathrm{U} \cdot \mathrm{g}_{\text {protein }}^{-1}\right)$ & 225 & $29^{\mathrm{a}, \mathrm{c}}$ & 167 & 31 & 168 & 14 & 194 & 29 \\
\hline
\end{tabular}

a,b $P<0.05, P<0.01$, compared to PR, ${ }^{\mathrm{c}, \mathrm{d}} P<0.05, P<0.01$, compared to ND, ${ }^{\text {e,f }} P<0.05, P<0.01$ compared to FF; for definitions see Fig. 2

PR rats (Table $2, P<0.01$ ). The LDH and HAD activities were not significantly different among the groups (Table 2). Activity of CS was significantly increased in the TR rats compared to the PR and ND rats (Table 2, $P<0.05)$. The mean ratio of CS over PFK activity was significantly decreased in the TR group [0.6 (SEM 0.1)] compared to FF $[3.3$ (SEM 0.9)] $(P<0.01)$ and PR $[1.6$ (SEM 0.5)] $(P<0.05)$.

\section{Discussion}

This study demonstrated that the triamcinolone-induced effects on muscle enzyme capacity were not related to the reduction in muscle mass per se, or corticosteroid treatment per se, but to underlying metabolic changes different from nutritional deprivation or prednisolone treatment.

Triamcinolone treatment caused a relative increase in energy intake after 9 days, considering the food intake per $100 \mathrm{~g}$ body mass. However the reduction in muscle mass was even more pronounced in TR rats than in ND rats. This would imply an increased energy expenditure and an increased net protein degradation in the TR rats. The ND caused a reduction in body mass, but the reduction in muscle mass was relatively small, which could be expected in view of the metabolic adaptations to starvation, that is increased fat oxidation instead of net protein degradation. In contrast to triamcinolone, prednisolone caused no alterations in energy intake or muscle mass. Tibialis anterior muscle mass relative to body mass was even increased similar to nutritional deprivation. These findings were in line with earlier studies, in which it has been shown that in contrast to oral treatment or subcutaneous administration of prednisolone (Dodd et al. 1995; Kelly et al. 1986; Lieu et al. 1993), intramuscular treatment of prednisolone has appeared to cause no catabolism (Dekhuijzen et al. 1993; Faludi et al. 1966).

The observed increase in muscle glycogen content would seem to be induced by corticosteroids per se, since enhanced glycogen contents were observed in the tibialis anterior muscle of both TR and PR treated ani- mals. However, the increase was significantly higher after treatment with the fluorinated corticosteroid triamcinolone than after prednisolone administration. The substantially increased glycogen content after triamcinolone treatment was accompanied by an increased GS(i $+d)$ activity, which was caused by an increase of the inactive form GS(d). When this enzyme is dephosphorylated, it becomes active [GS(i)]. After triamcinolone treatment, the supply of phosphorylated GS is increased, which may be surplus. The observation of increased GS activity corroborates earlier findings of Peters et al. (1970), who have not distinguished between the active and inactive forms. In contrast, the increased glycogen content after prednisolone treatment was not accompanied by alterations in the maximal activity of GP or GS. These findings would suggest that glycogen synthesis is regulated by factors other than the content (i.e. maximal activity) of GS or GP, which supports the allosteric activity of GS by glucose. Nutritional deprivation resulted in an expected decrease of glycogen content in the tibialis anterior muscle (Brown 1986; Conlee et al. 1976; Russell et al. 1984a, 1984b), without alterations in the maximal activity of glycogen handling enzymes.

Both PFK and CS enzyme capacities were increased in the tibialis anterior muscle after triamcinolone treatment, implying an increase in both glycolytic and oxidative enzyme capacity. This could also have been an indirect result of muscle wasting with a marked loss of contractile proteins and a relative preservation of metabolic proteins, but in that case, all muscle enzyme capacities would have had to be increased, which was not observed in this study. The fact that the increase of PFK was more pronounced than that of CS would indicate that the glycolytic pathway was more sensitive to triamcinolone treatment than the citric acid cycle. In the present study, oxidative phosphorylation was not studied, but earlier studies have shown that oxidative phosphorylation and respiration in isolated mitochondria obtained from muscle tissue were less tightly coupled after triamcinolone treatment (Peter et al. 1970; Vignos and Greene 1973). The consequence of relative uncoupling is most 
likely to be the upregulation of enzyme activities involved in the rate determining steps of glycolysis and citric acid cycle activity as observed in the present study, in order to obtain sufficient adenosine triphosphate.

In contrast to the increase of PFK activity after triamcinolone treatment, we observed after prednisolone treatment no alterations in PFK activity in the muscle, while Lieu et al. (1993) have even found a decrease of PFK activity. The results of these studies are difficult to compare because of the differences in treatment and types of muscles under investigation. Lieu et al. (1993) have injected higher doses of prednisolone than in the present study and injected it subcutaneously, which induced catabolism. The ND in the present study caused no alteration in PFK, while Russell et al. (1984a) fed rats $25 \%$ of their normal diet over 3 weeks after which they observed a decrease in PFK capacity in the gastrocnemius muscle. Despite a decreased glycogen concentration and wasting of the tibialis anterior muscle after $\mathrm{ND}$, no alterations in the maximal activity of enzymes involved in carbohydrate and $\beta$-oxidation were observed in the present study.

It has been suggested that several factors may contribute to muscle wasting and muscle weakness in patients with COPD, including nutritional depletion (Engelen et al. 1994), corticosteroid medication (Decramer et al. 1994), acute respiratory failure (Fiaccadori et al. 1987) and inactivity (Maltais et al. 1996). In this study we found that corticosteroids led to increased muscle glycogen contents and may have induced a type specific upregulation of enzymes of carbohydrate metabolism. Undernutrition was associated with glycogen depletion but not to major changes in these enzymes. Both increased muscle glycogen contents (Pouw et al. 1998) and decreased glycogen contents (Jakobsson and Jorfeldt 1995) have previously been reported in patients with COPD. Altered PFK and CS activities have also been demonstrated in muscles of COPD patients (Jakobsson et al. 1995; Maltais et al. 1996), but the pattern of changes has not been consistent among the studies. Furthermore, a very recent study showed in skeletal muscle of COPD patients an upregulation of the activity and gene expression of cytochrome oxidase (Sauleda et al. 1998). Further studies are needed to determine whether biochemical analysis of peripheral muscle biopsies could be useful in differentiating between the specific contributions of nutritional depletion and corticosteroids in patients with COPD, aimed at targeted intervention strategies.

\section{References}

Bergmeyer HU (1974) Methods of enzymatic analysis 1:480-482

Bradshaw RA, Noyes BE (1975) L-3-hydroxyacyl Coenzyme A dehydrogenase from pig heart muscle. Methods Enzymol $35: 122-128$

Brown DH (1986) Glycogen metabolism and glycolysis in muscle. In: Engel A, Banker B (eds) Myology, basic and clinical. McGraw-Hill, New York, pp 673-696
Brown R, Jarvis K, Hyland K (1989) Protein measurement using bicinchoninic acid: elimination of interfering substances. Anal Biochem 180:136-139

Conlee RK, Rennie MJ, Winder WW (1976) Skeletal muscle glycogen content: diurnal variation and effects of fasting. Am $\mathbf{J}$ Physiol 231:614-618

Danforth W (1965) Glycogen synthetase activity. Interconversion of two forms and control of glycogen synthesis. J Biol Chem 240:588-593

Decramer M, Lacquet LM, Fagard R, Rogiers P (1994) Corticosteroids contribute to muscle weakness in chronic airflow obstruction. Am J Respir Crit Care Med 150:11-16

Dekhuijzen PNR, Gayan Ramirez G, Bock V de, Dom R, Decramer M (1993) Triamcinolone and prednisolone affect contractile properties and histopathology of rat diaphragm differently. J Clin Invest 92:1534-1542

Dekhuijzen PNR, Gayan Ramirez G, Bisschop A, Bock V de, Dom R, Decramer M (1995) Corticosteroid treatment and nutritional deprivation cause a different pattern of atrophy in rat diaphragm. J Appl Physiol 78:629-637

Dodd SL, Powers SK, Vrabas IS, Eason JM (1995) Interaction of glucocorticoids and activity patterns affect muscle function. Muscle Nerve 18:190-195

Engelen MPKJ, Schols AMWJ, Baken WC, Wesseling GJ, Wouters EFM (1994) Nutritional depletion in relation to respiratory and peripheral skeletal muscle function in out-patients with COPD. Eur Respir J 7:1793-1797

Faludi G, Gotlieb J, Meyers J (1966) Experimentally induced primary myopathies. Factors influencing the development of steroid-induced myopathies. Ann NY Acad Sci 138:61-72

Ferguson GT (1993) Corticosteroids and respiratory muscles. Does it matter? Chest 104:1649-1650

Fiaccadori E, Del CS, Vitale P, Coffrini E, Ronda N, Guariglia A (1987) Skeletal muscle energetics, acid-base equilibrium and lactate metabolism in patients with severe hypercapnia and hypoxemia. Chest 92:883-887

Gardiner PF, Montanaro G, Simpson DR, and Edgerton VR (1980) Effects of glucocorticoid treatment and food restriction on rat hindlimb muscles. Am J Physiol 238:E124 E130

Goodman LS, Gillman A (1990) Adrenocortical steroids. The pharmacological basis of therapeutics. Pergaman Press, New York, pp 1436-1462

Gosselink R, Troosters T, Decramer M (1996) Peripheral muscle weakness contributes to exercise limitation in COPD. Am J Respir Crit Care Med 153:976-980

Hamilton AL, Killian KJ, Summers E, Jones NL (1995) Muscle strength, symptom intensity, and exercise capacity in patients with cardiorespiratory disorders. Am J Respir Crit Care Med 152:2021-2031

Jakobsson P, and Jorfeldt L (1995) Long-term oxygen therapy may improve skeletal muscle metabolism in advanced chronic obstructive pulmonary disease patients with chronic hypoxaemia. Respir Med 89:471-476

Jakobsson P, Jorfeldt L, and Henriksson J (1995) Metabolic enzyme activity in the quadriceps femoris muscle in patients with severe chronic obstructive pulmonary disease. Am J Respir Crit Care Med 151:374-377

Kelly FJ, McGrath JA, Goldspink DF, Cullen MJ (1986) A morphological / biochemical study on the actions of corticosteroids on rat skeletal muscle. Muscle Nerve 9:1-10

Koerts-de Lang E, Schols AMWJ, Deutz NEP, Blaauw I de, Wouters EFM (1995) Effects of combined prolonged corticosteroid treatment and undernutrition on muscle glutamine metabolism in rats. Am J Resp Crit Care Med 151:A812

Koerts-de Lang E, Schols AMWJ, Deutz NEP, Wouters EFM (1997) Attenuated effects of prednisolone treatment on muscle glutamine and protein metabolism during nutritional deprivation in rats. Am J Resp Crit Care Med 155:A921

Koerts-de Lang E, Schols AMWJ, Gayan-Ramirez G, Wouters EFM, Decramer M (1998) Contractile properties and histochemical characteristics of the rat diaphragm after prolonged 
triamcinolone treatment and nutritional deprivation. J Muscle Res Cell Motil 19:549-555

Lieu FK, Powers SK, Herb RA, Criswell D, Martin D, Wood C, Stainsby W, Chen CL (1993) Exercise and glucocorticoidinduced diaphragmatic myopathy. J Appl Physiol 75:763-771

Ling KH, Peatkau V, Marcus F, Lardy HA (1966) Phosphofructokinase Methods Enzymol 9:425-429

Maltais F, Simard A, Simard C, Jobin J, Desgagnes P, LeBlanc P (1996) Oxidative capacity of the skeletal muscle and lactic acid kinetics during exercise in normal subjects and in patients with COPD. Am J Respir Crit Care Med 153:288-293

Peter JB, Verhaag DA, Worsfold M (1970) Studies of steroid myopathy. Examination of the possible effect of triamcinolone on mitochondria and sarcotubular vesicles of rat skeletal muscle. Biochem Pharmacol 19:1627-1636

Peters RF, Richardson MC, Small M, White AM (1970) Some biochemical effects of triamcinolone acetonide on rat liver and muscle. Biochem J 116:349-355

Petrof BJ, Gottfried SB, Eby J, Lamanca J, Levine S (1995) Growth hormone does not prevent corticosteroid-induced changes in rat diaphragm structure and function. J Appl Physiol 79:1571-1577

Pouw E, Schols A, Vusse G van der, Wouters E (1998) Elevated inosine monophosphate levels in resting muscle of patients with stable chronic obstructive pulmonary disease. Am J Respir Crit Care Med 157:453-457.

Russell DM, Atwood HL, Whittaker JS, Itakura T, Walker PM, Mickle DAG, Jeejeebhoy KN (1984a) The effect of fasting and hypocaloric diets on the functional and metabolic characteristics of rat gastrocnemius muscle. Clin Sci 67:185-194

Russell DM, Walker PM, Leiter LA, Sima AAF, Tanner WK, Mickle DAG, Whitwell J, Marliss EB, Jeejeebhoy KN (1984b)
Metabolic and structural changes in skeletal muscle during hypocaloric dieting. Am J Clin Nutr 39:503-513

Sauleda J, GarciaPalmer F, Wiesner R, Tarraga S, Harting I, Toma P, Gomez C, Saus C, Palou A, Agusti A (1998) Cytochrome oxidase activity and mitochondrial gene expression in skeletal muscle of patients with chronic obstructive pulmonary disease. Am J Respir Crit Care Med 157:14131417

Schreiber WE, Bowling S (1990) An automated assay of glycogen phosphorylase in the direction of phosphorolysis. Ann Clin Biochem 27:129-132

Shepherd D, Garland PB (1969) Citrate synthase from rat liver. Methods Enzymol 13:11-16

Shoji S, Takagi A, Sugita H, Toyokura Y (1974) Muscle glycogen metabolism in steroid-induced myopathy of rabbits. Exp Neurol 45:1-7

Smith PK, Krohn RI, Hermanson GT, Mallia AK, Gartner FH, Provenzano MD, Fujimoto EK, Goeke NM, Olson BJ, Klenk DC (1985) Measurement of protein using bicinchoninic acid. Anal Biochem 150:76-85

Thalen A, Brattsand R, Andersson PH (1989) Development of glucocorticoids with enhanced ratio between topical and systemic effects. Acta Derm Venereol 69:11-19

Tobin MJ (1988) Respiratory muscles in disease. Clin Chest Med 9:263-286

Vignos PJ, Greene R (1973) Oxidative respiration of skeletal muscle in experimental corticosteroid myopathy. J Lab Clin Med 81:365-378

Welbourne TC (1988) Role of glucocorticoids in regulating interorgan glutamine flow during chronic metabolic acidosis. Metabolism 37:520-525 